\author{
ИССЛЕДОВАНИЕ СНЕЖНОГО ПОКРОВА \\ ПРАВОБЕРЕЖНОЙ ЧАСТИ Г. ДУБНА \\ И ВОД РЕК ВОЛГА И ДУБНА \\ Федорук Н.А., Кирпичев И.А. \\ ГБОУ ВО МО «Университет «Дубна», Дубна, \\ e-mail:fedoruk_dubna@mail.ru, il.kirpi4iov@yandex.ru
}

\begin{abstract}
Данная статья посвящена исследованию химического состава жидкой фазы свежевыпавшего снега в правобережной части наукограда Дубна, а также поверхностных вод рек Волга и Дубна с выявлением превалирующих загрязняющих компонентов. Для выявления загрязняющих веществ, содержащихся в снежном покрове, был проведен пробоотбор по требованиям ГОСТ 17.1.5.05-85, в девяти точках исследования, среди которых можно выделить характерные зоны: автомагистрали, территории вблизи промышленных предприятий, лесные массивы, а также жилые районы и одна фоновая точка вблизи района Ратмино. Отбор проб воды производился в 7 точках на Угличском водохранилище (р. Волга) в пределах г. Дубна, а также на р. Дубна в соответствии с ГОСТ 31861-2012. Химический анализ проведен в эколого-аналитической лаборатории анализа объектов окружающей среды кафедры экологии и наук о Земле государственного университета «Дубна». Анализ проб жидкой фазы снежного покрова и речной воды осуществлялся по следующим компонентам: взвешенные вещества, ион аммония, кадмий, кальций, магний, медь, никель, нитрит-ион, общая жесткость, pH, свинец, фосфат-ион, цинк. В ходе работ получены данные по загрязняющим компонентам жидкой фазы снега и вод рек, расположенных в черте г. Дубна. Исследование показало превышение ПДК(рх) по меди, свинцу, цинку и фосфатам в анализируемых средах. В ходе исследования получены данные, которые будут использованы для вынесения предложений и рекомендаций по улучшению качества окружающей среды г. Дубна, а также для продолжения ведения статистики.
\end{abstract}

Ключевые слова: снег, снежный покров, загрязнение, г. Дубна, Волга, водохранилище

\title{
STUDY OF THE SNOW COVER OF THE RIGHT BANK OF DUBNA AND THE WATERS VOLGA AND DUBNA RIVERS
}

\author{
Fedoruk N.A., Kirpichev I.A.
}

Dubna State University,Dubna, e-mail:_edoruk_dubna@mail.ru, il.kirpi4iov@yandex.ru

\begin{abstract}
This article is devoted to the study of the chemical composition of the liquid phase of freshly fallen snow in the right-bank part of the Dubna science city, as well as the waters of the Volga and Dubna rivers with the identification of prevailing polluting components. To identify pollutants contained in the snow cover, sampling was carried out in accordance with the requirements of GOST 17.1.5.05-85, at nine points of the study, among which there are characteristic zones: highways, territories near industrial enterprises, forests, as well as residential areas and one background point on Ratmino. Water sampling was carried out at 7 points on the Uglich reservoir within the city of Dubna, as well as on the Dubna River in accordance with GOST 31861-2012. Chemical analysis of samples of the liquid phase of snow and water was carried out for the following components: suspended solids, ammonium ion, cadmium, calcium, magnesium, copper, nickel, nitrite ion, total hardness, $\mathrm{pH}$, lead, phosphate ion and zinc. In the course of the work, data were obtained on the polluting components of the liquid phase of snow and river waters located within the city of Dubna. The study showed the excess of MPC for copper, lead, zinc and phosphates in the analyzed media. In the course of the work, data were obtained that will be used to make proposals and recommendations for improving the quality of the environment in Dubna, as well as for maintaining statistics.
\end{abstract}

Keywords: snow, snow cover, pollution, Dubna, Volga, reservoir

Снежный покров является эффективным накопителем аэрозольных загрязняющих веществ, выпадающих из атмосферного воздуха. При снеготаянии данные вещества поступают в природные среды, главным образом в воду и почвы $[1 ; 2]$.

При образовании и выпадении снега в результате процессов сухого и влажного вымывания концентрация загрязняющих веществ в нем оказывается обычно на несколько порядков выше, чем в атмосферном воздухе [2; 3].

Работы по выявлению загрязняющих компонентов в снежном покрове урбанизированных территорий проводятся по- всеместно на территории России и зарубежных стран в связи с простотой метода и высокой степенью надежности $[2 ; 3]$.

Подобные исследования проводились в 2007 году в г. Дубна. В работах авторских коллективов [4] проанализировано 12 различных компонентов по каждой точке в черте города. Данное исследование опирается на опубликованные ранее данные и продолжает работу, начатую более 10 лет назад.

Целью исследования является определение концентраций загрязняющих веществ в жидкой фазе свежевыпавшего снега на территории правого берега г. Дубна, а также в водах рек Волга и Дубна. 
Задачи исследования:

1) произвести отбор свежевыпавшего снега и проб воды из р. Волга в районе г. Дубна;

2) выполнить лабораторный анализ проб;

3) сделать выводы о состоянии снежного покрова г. Дубна в 2020 г. и рассмотреть возможность поступления загрязняющих компонентов с поверхностным стоком в Угличское водохранилище.

Город Дубна является активно развивающимся наукоградом. Для него характерно увеличение количества населения, а также различных промышленных предприятий. Основным градообразующим предприятием является Объединенный институт ядерных исследований (ОИЯИ), немаловажна роль Особой экономической зоны «Дубна». На территории города расположены 4 котельные, а также несколько предприятий, специализирующихся на производстве приборов и машиностроении. Растет роль выбросов от автомобильного транспорта, число которого коррелирует с численностью населения [5].

В работе использованы как теоретические, так и эмпирические методы. Лабораторный анализ проводился при помощи мобильных приборов, таких как рН-метр «рН-150МИ», и спектрофотометра «КФК3ОМ3» (ион аммония, нитрит-ион, фосфатион). Также использовался титриметрический метод для определения жесткости воды, содержания ионов кальция и магния, помимо этого, для определения концентрации тяжелых металлов применен атомноабсорбционный метод с использованием спектрометра «КВАНТ-2А».

Наукоград Дубна находится на севере Московской области, в 125 км от Москвы, площадь города - 6336 га. С четырех сторон Дубна окружена водными объектами: p. Волгой (Иваньковское и Угличское водохранилища), рр. Дубной и Сестрой, а также каналом им. Москвы [6]. Средняя годовая температура территории Дубны, по данным многолетних метеонаблюдений, составляет $+3,4{ }^{\circ} \mathrm{C}$. Зима умеренно холодная. Средняя температура воздуха самого холодного месяца - января - составляет $-10,7^{\circ} \mathrm{C}$. Лето теплое. Средняя температура воздуха самого теплого месяца (июль) равна $+17,8^{\circ} \mathrm{C}$ [6]. Обилие водных ресурсов оказывает влияние на температурный режим, снижая в летнее время температуру на $2-4{ }^{\circ} \mathrm{C}$, в то время как в осеннее время воздействие водных масс оказывает отепляющее влияние, поднимая температуру на 3-6 C [7]. Дубна расположена среди лесных массивов. В северном направлении от долины р. Волги распро- странены сильно заболоченные бореальные леса, а югу от города начинаются смешанные широколиственно-хвойные леса.

По данным из последних отчетов [7], г. Дубна характеризуется благоприятной экологической обстановкой, хотя спектр производств довольно широк, превышений предельно допустимых концентраций (ПДК) вредных веществ в атмосферном воздухе не выявляется, но обратить внимание на данную проблему необходимо, так как за последние 20 лет в инфраструктуре города произошли существенные изменения. Интенсивная застройка правобережья определенно внесла вклад в загрязнение территории данного населенного пункта. Кроме того, сегодня наиболее существенной проблемой всех городов Подмосковья, в том числе и Дубны, является рост количества личного легкового автотранспорта, который привносит загрязняющие вещества в атмосферный воздух, ухудшая качество жизни населения. Среди стационарных источников загрязнения основными являются котельные.

\section{Материалы и методы исследования}

Отбор проб из снежного покрова проводился в соответствии со следующими нормативными документами [8-10] в период его максимального накопления, незадолго до периода снеготаяния. В связи с малоснежной зимой 2020 года (что не характерно для Дубны) отбор проб осуществлен 10.02.2020 года, при температуре воздуха $+2{ }^{\circ} \mathrm{C}$, когда снег только начал таять. Пробы отбирались вблизи источников антропогенного воздействия (автомагистрали, промышленные предприятия), а также в лесных массивах и жилых районах. Таким образом, обозначено 9 точек исследования (рис. 1). Пластиковый пробоотборник погружался на всю глубину снежного массива, до границы с почвенным покровом. Было исключено попадание частиц почвы в пробу. Далее снег складировался в чистую пластиковую тару объемом 5 литров, что при таянии соответствовало 2-2,5 литрам талой воды. После отбора по намеченным точкам пробы транспортировались в лабораторию.

Отбор проб воды производился в соответствии с методикой ГОСТ 31861-2012 [11] при помощи телескопического пробоотборника длиной 3 метра с берега. Для вод р. Волга в районе г. Дубна характерно отсутствие льда во время зимнего периода, что связано с высокой скоростью течения воды и её аэрацией в результате прохождения через плотину Иваньковской ГЭС. Отбор производился в точках, обозначенных на рисунке 2 . 


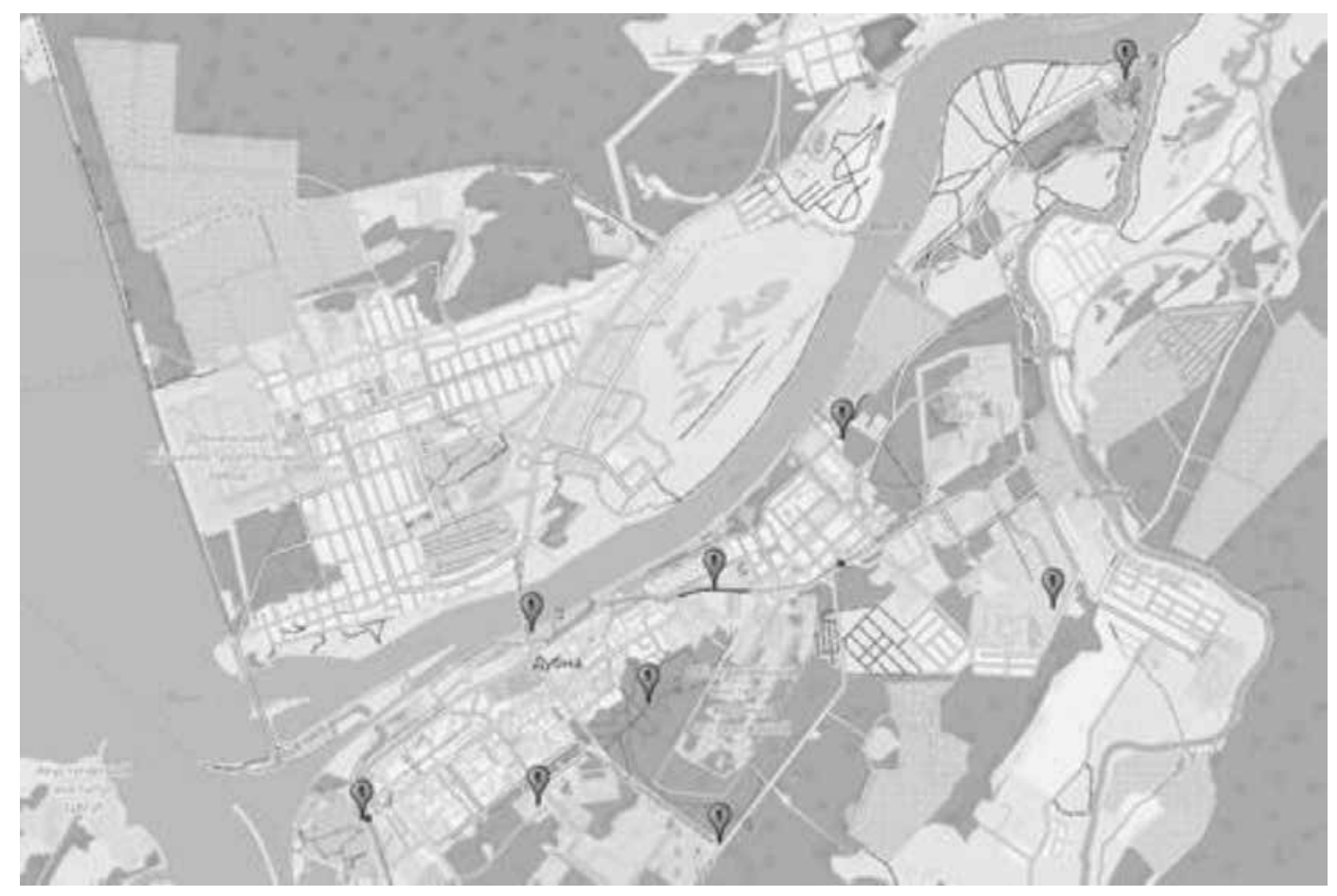

Рис. 1. Карта расположения точек отбора снега на территории правого берега г. Дубна: 1 - Дмитровское шоссе; 2 - территория у предприятия АО «Энергия-Тензор»;

3 - Дубненский мост; 4 - перекресток на Новом шоссе; 5 -лесной массив у пика Тяпкина; 6 - котельная на ул. Молодежная; 7 -жилой двор в Институтской части; 8 - Завод железобетонных изделий (ЗЖБИ); 9 - Ратмино

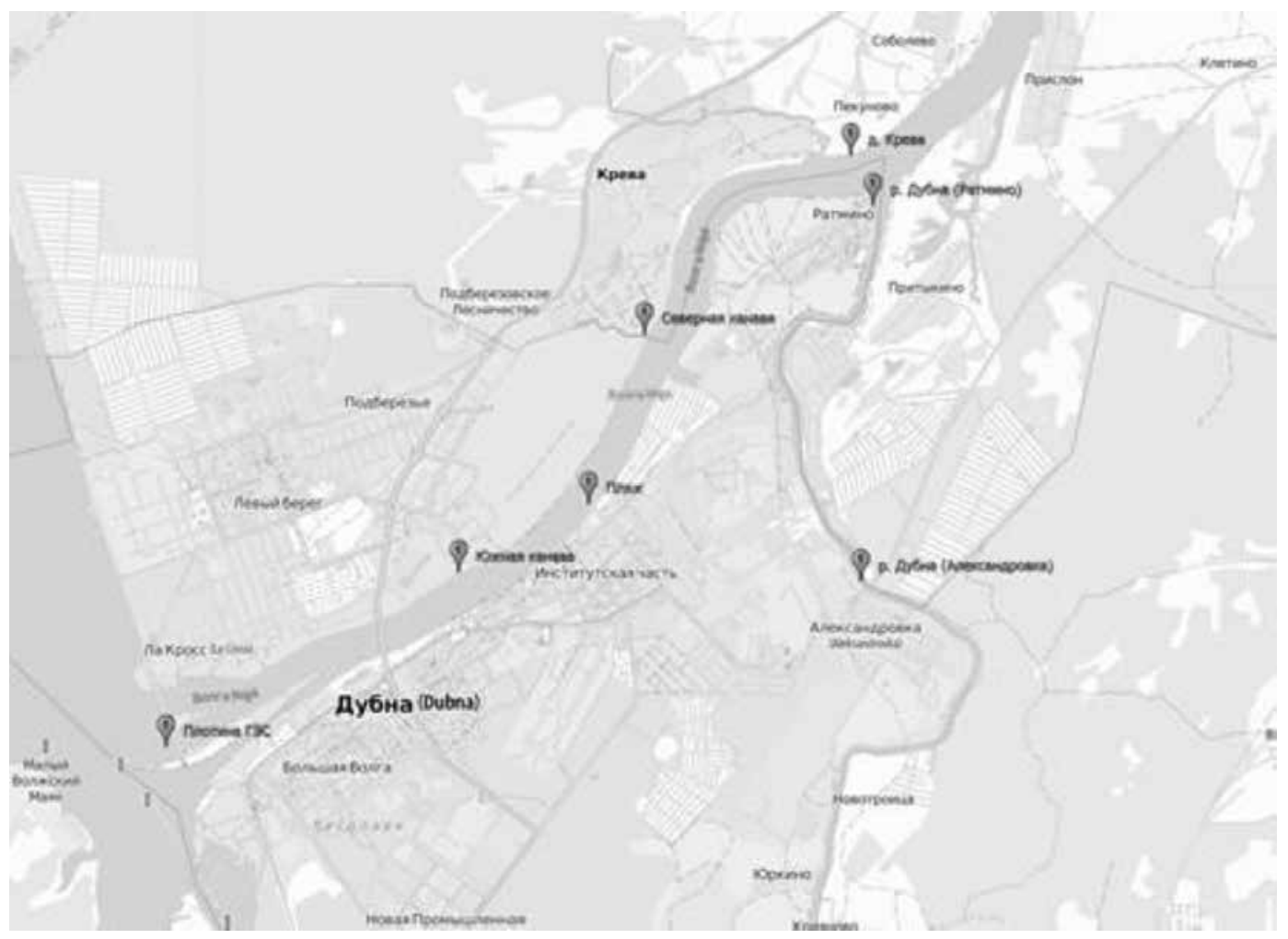

Рис. 2. Карта створов отбора проб воды на р. Волга в районе г. Дубна:

1 - плотина ГЭС; 2 - Южная канава; 3 - пляж; 4 - Северная канава; 5 - д. Крева; 6 - p. Дубна (Александровка); 7 - р. Дубна (Ратмино) 
После отбора пробы снега были растоплены в лаборатории при комнатной температуре без использования подогревающих средств.

Для определения взвешенных веществ, присутствующих в снежном покрове в виде частиц пыли, песка и т.д., пробы фильтровались через фильтр синяя лента, после чего высушивались при температуре $100^{\circ} \mathrm{C}$ до стабильного значения.

В пробах снеговой талой воды и поверхностных вод были определены: величина $\mathrm{pH}$, общая жесткость, кальций, магний, взвешенные вещества, аммоний-ион $\left(\mathrm{NH}_{4}^{+}\right)$, нитрит-ион $\left(\mathrm{NO}_{2}^{-}\right)$, фосфат-ионы, тяжелые металлы (медь $(\mathrm{Cu})$, цинк $(\mathrm{Zn})$, свинец $(\mathrm{Pb})$, кадмий (Cd), никель (Ni)).

Кислотность измерялась с помощью pН-метра «рН-150МИ» с использованием стеклянного комбинированного электрода, который погружался в анализируемую пробу. После установки стабильных значений показания фиксировались.

Общая жесткость и кальций определялась титриметрическим методом с применением соответствующих реактивов, после чего из полученных данных выводились концентрации магния.

Аммоний-ион, нитрит-ион, фосфат-ион определены с помощью фотометрического метода на спектрофотометре «КФК-30МЗ».

Концентрации тяжелых металлов $(\mathrm{Cu}$, $\mathrm{Zn}, \mathrm{Cd}, \mathrm{Ni}, \mathrm{Pb})$ - методом атомно-абсорбционной спектрометрии на приборе АAC «Квант 2А».

Любой результат анализа имеет погрешность определения. Поэтому на следующей стадии исследования проводилась статистическая обработка результатов. Было выявлена случайная погрешность при измерении свинца (методом атомной абсорбции) на приборе «Квант 2А», которую устранили увеличением количества измерений до прекращения расхождения значений.

При построении картосхем пространственного распределения тяжелых металлов в снеготалой воде использовался программный комплекс Surfer.

При оценке загрязненности снеговых и поверхностных вод использованы нормативы для воды водных объектов, имеющих рыбохозяйственное значение. Использование ПДК(рх) обусловлено тем, что Угличское водохранилище является водоемом рыбохозяйственного значения, в котором обитают ценные виды рыб (жерех, судак, щука, сом пресноводный, сазан, налим, голавль, лещ и др.), популяция которых постоянно контролируется. Кроме того, выбор осуществлен в связи с необходимостью оценки максимальной потенциальной опасности смыва талых снеговых вод в реки Волга и Дубна.

Несмотря на то что Угличское водохранилище питается преимущественно грунтовыми водами, нельзя исключать воздействие талых снеговых вод. Вместе с ними в водоём могут поступать различные химические компоненты природного и антропогенного генезиса.

\section{Результаты исследования и их обсуждение}

Результаты обработки результатов химического анализа снеговых и поверхностных вод (максимальные, минимальные и средние значения) представлены в таблице 1 .

По результатам проведенного химического анализа на загрязняющие компоненты жидкой фазы снега мы рассмотрели полученные значения более подробно и сделали следующие выводы.

По водородному показателю все пробы снеготалой воды показали близкие друг к другу значения, которые колебались от 6,4 до 7,5 ед. $\mathrm{pH}$.

По результатам анализа проб снега на общую жесткость талая вода не превышала 2,0 мг-экв/л, что говорит о мягкости воды. Наиболее высокие показатели выявлены у Дубненского моста, а также у Завода железобетонных изделий (ЗЖБИ) и составили 1,5 и 1,22 мг-экв/л соответственно.

Концентрации кальция и магния изменялись соответственно в пределах от 0,8 до 21,2. Так, максимальное значение по кальцию составляет 21,2 мг/дм ${ }^{3}$, по магнию - 5,4 мг/дм ${ }^{3}$ в точке у Дубненского моста.

Наивысшие значения взвешенных веществ обнаружены в трех точках, а именно у Дмитровского шоссе $\left(8,6\right.$ мг/дм $\left.{ }^{3}\right)$, Дубненского моста $\left(3,9\right.$ мг/дм $\left.{ }^{3}\right)$ и ЗЖБИ $(21,8$ мг/ дм$\left.^{3}\right)$. Дмитровское шоссе в точке исследования отличается непрерывным потоком транспорта в связи с расположением поблизости двух автозаправочных станций. Соответственно, наблюдается постоянный приток мелкой пыли. Аналогичная ситуация в точке около Дубненского моста. Точка у ЗЖБИ, помимо потока автотранспорта (в том числе грузового), характеризуется привнесением пылеватых частиц из промышленной зоны, окружающей точку исследования.

Среди растворенных ионных комплексов снежного покрова были рассмотрены аммоний-ион $\left(\mathrm{NH}_{4}^{+}\right)$, нитрит-ион $\left(\mathrm{NO}_{2}^{-}\right)$и 
фосфат-ион $\left(\mathrm{PO}_{4}{ }^{3-}\right)$. Значения аммоний-иона представлены в диапазоне от 0,09 до 0,41 мг/дм ${ }^{3}$, нитрит-иона - от 0,017 до 0,082 мг/дм ${ }^{3}$, фосфат-иона - от 0,005 до 0,4 мг/дм ${ }^{3}$.

Наибольшие значения концентрации ионов аммония наблюдаются в точке у Дмитровского шоссе, где показатели составляют 0,41 мг/дм ${ }^{3}$. Анализ нитрит-ионов не показал превышений ПДК(рх). Фосфат-ионы превышают ПДК(рх) в точке у Дмитровского шоссе и показали максимальное значение 0,4 мг/дм³ ${ }^{3}$ Вероятно, это связано с обилием органических отходов, чему способствуют оживленная автомагистраль и железнодорожная станция Большая Волга, а также расположенная неподалеку автомойка.

Наибольший интерес в ходе исследования вызывали концентрации тяжелых металлов $(\mathrm{Cu}, \mathrm{Zn}, \mathrm{Cd}, \mathrm{Ni}, \mathrm{Pb})$. Присутствие в депонирующей среде тяжелых металлов на исследуемой территории связано в основном с антропогенной деятельностью.

Концентрации, превышающие ПДК(рх), обнаружены по меди у Завода железобетонных изделий, по свинцу - в жилом дворе
Институтской части, а также по цинку практически во всех точках, за исключением фоновой на ул. Ратмино и у Дубненского моста.

По результатам анализа тяжелых металлов в программном комплексе Surfer построены картосхемы распределения исследуемых элементов, превышающих ПДК(рх) (рис. 3).

Таким образом, рассмотренный перечень загрязняющих компонентов позволяет создать определенную картину экологического состояния территории и выявить нагрузку на подземные воды и водоемы в период снеготаяния. Ниже представлена сводная таблица по результатам анализа снежного покрова и вод р. Волга.

В отличие от снежного покрова, воды p. Волга в районе г. Дубна отличаются более высокой минерализацией, на что указывают значения общей жесткости. Для вод р. Волга характерны практически те же контаминанты, что и для снежного покрова города, что дает основания говорить о влиянии снежного покрова на качество вод. Снежный покров города содержит большое количество пылевых и взвешенных веществ, что было обнаружено при анализе.

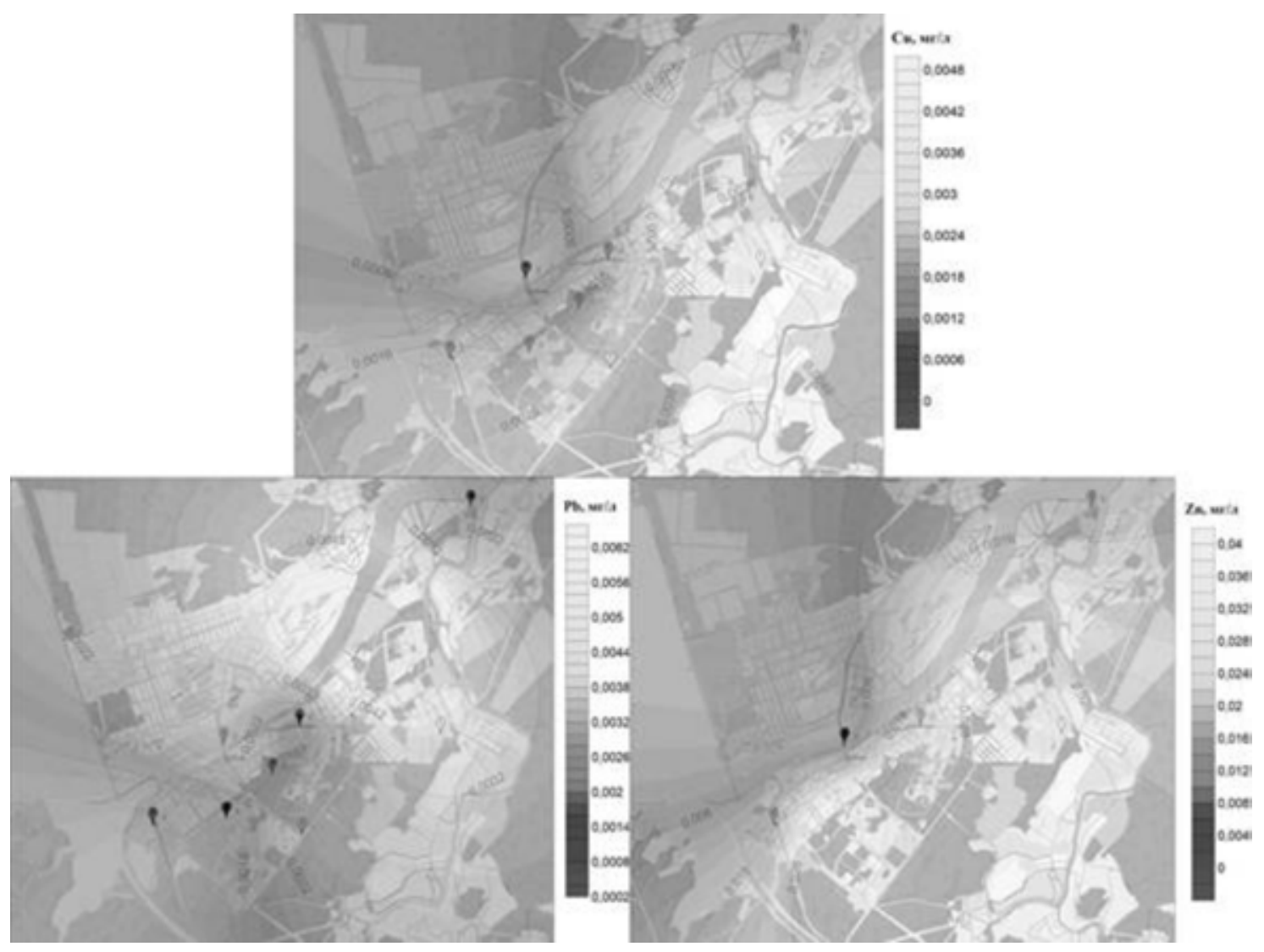

Рис. 3. Картосхемы концентраций меди, свинца, цинка в жидкой фазе снежного покрова на территории правого берега г. Дубна 
Таблица 1

Сравнение качества снежного покрова и поверхностных вод р. Волга

\begin{tabular}{|l|c|c|c|c|c|c|c|c|c|}
\hline \multirow{2}{*}{ Показатель } & \multicolumn{3}{|c|}{ Снежный покров (2020 г.) } & \multicolumn{4}{c|}{ р. Волга (2020 г.) } & \multirow{2}{*}{ ПДКрх } \\
\cline { 2 - 10 } & Среднее & Мин. & Макс. & $\begin{array}{c}\text { Сp. } \\
\text { отклонение }\end{array}$ & Среднее & Мин. & Макс. & $\begin{array}{c}\text { Сp. } \\
\text { отклонение }\end{array}$ & \\
\hline $\begin{array}{l}\text { Взвешенные } \\
\text { вещества }\end{array}$ & 4,26 & 0,30 & $\mathbf{2 1 , 8 0}$ & 4,86 & 6,0 & 1,0 & $\mathbf{1 0 , 4}$ & 2,4 & 1,5 \\
\hline Ион аммония & 0,26 & 0,09 & 0,41 & 0,08 & 0,3 & 0,2 & $\mathbf{0 , 5}$ & 0,1 & 0,5 \\
\hline Кадмий & 0,0002 & 0,0001 & 0,0003 & 0,00 & 0,0002 & 0,0001 & 0,0002 & 0,0001 & 0,001 \\
\hline Кальций & 6,86 & 0,80 & 21,24 & 5,85 & 40,2 & 33,7 & 76,6 & 9,1 & 180 \\
\hline Магний & 8,59 & 2,43 & 23,57 & 6,32 & 47,4 & 39,7 & $\mathbf{9 0 , 4}$ & 10,7 & 40 \\
\hline Медь & 0,002 & 0 & $\mathbf{0 , 0 0 5}$ & 0,00 & 0,003 & 0,002 & $\mathbf{0 , 0 0 8}$ & 0,001 & 0,001 \\
\hline Никель & 0,001 & 0,0004 & 0,001 & 0,02 & 0,001 & 0,001 & 0,003 & 0,000 & 0,1 \\
\hline Нитрит-ион & 0,043 & 0,017 & 0,082 & 0,016 & 0,028 & 0,005 & 0,115 & 0,024 & 3 \\
\hline $\begin{array}{l}\text { Общая } \\
\text { жесткость }\end{array}$ & 0,52 & 0,16 & 1,5 & 0,41 & 3,0 & 2,5 & 5,6 & 0,7 & 10 \\
\hline рН & 6,78 & 6,4 & 7,5 & 0,33 & 8,2 & 8,1 & $\mathbf{8 , 6}$ & 0,2 & $6,5-8,5$ \\
\hline Свинец & 0,002 & 0,0004 & $\mathbf{0 , 0 0 6}$ & 0,00 & 0,002 & 0,000 & $\mathbf{0 , 0 0 5}$ & 0,001 & 0,002 \\
\hline Фосфат-ион & 0,12 & 0,005 & $\mathbf{0 , 4}$ & 0,07 & 0,1 & 0,0 & $\mathbf{0 , 2}$ & 0,1 & 0,2 \\
\hline Цинк & 0,023 & 0,0053 & $\mathbf{0 , 0 3 8}$ & 0,01 & 0,026 & 0,016 & $\mathbf{0 , 0 4}$ & 0,007 & 0,01 \\
\hline
\end{tabular}

Очевидно, что содержание взвешенных веществ в снежном покрове меньше, чем в воде р. Волга, однако снежный покров дает большой вклад в их поступление с поверхностным стоком. Зимой, особенно во время гололедицы, на дороги города вносится масса песка и глины, чтобы предотвратить скольжение. Во время снеготаяния все эти компоненты поступают в поверхностные воды.

Высокие концентрации цинка, часто превышающие ПДК, характерны как для снежного покрова, так и для вод р. Волга. Чаще всего этот загрязнитель характерен для оживленной городской территории, на которой происходит строительство.

Неоднозначная ситуация складывается в отношении меди и свинца. Медь - это компонент, характерный для изучаемой территории. Его высокие концентрации наблюдаются в воде р. Волга в течение всех периодов года. Вероятно, это природный фактор, связанный с питанием рек болотными водами. Свинец имеет антропогенное происхождение. В данном исследовании, в отличие от цинка, он мало характерен для городской территории. Это связано с переходом автомобилей на другой вид топлива, в котором отсутствуют антидетонационные присадки.

Повышенные концентрации свинца в снежном покрове обнаружены в обла- сти промышленной зоны правой части города. В целом, если касаться вод р. Волга, то в разных створах концентрация свинца является низкой. Вероятно, из снежного покрова данный компонент переходит в почвы и остается в ней.

Фоновой выделена точка 9, расположенная на ул. Ратмино. Данная местность находится в удалении от существенного антропогенного воздействия, которое оказывает г. Дубна на окружающую среду. Концентрации загрязняющих веществ в точке 9 представлены в таблице 2. Как видно из полученных значений, наблюдается превышение ПДК(рх) по меди, что связано с особенностями территории. Также стоит обратить внимание на содержание в снежном покрове других тяжелых металлов: свинца и цинка, которые фактически показывают значения на уровне ПДК(pх), но не превышают их. Остальные значения не выходят за границы предельно допустимых концентраций, как ожидалось, зафиксированы низкие показатели. Кроме того, концентрации большинства загрязняющих веществ фона ниже, чем в остальных точках исследуемой части г. Дубна.

Проведенные ранее исследования снежного покрова г. Дубна основаны на химическом анализе снега на всей территории города [6]. Автор определял величину $\mathrm{pH}$, содержание взвешенных веществ, сульфа- 
тов, нитратов, хлоридов, гидрокарбонатов, ионов аммония, кальция и магния, натрия и тяжелых металлов $(\mathrm{Cu}, \mathrm{Pb}, \mathrm{Zn}, \mathrm{Cd}, \mathrm{Ni}$, $\mathrm{Cr})$ [6]. Тяжелые металлы определялись в твердой фазе, в отличие от исследования 2020 года, где все компоненты определены в ходе анализа жидкой фазы снега. Были построены картосхемы с помощью программ MapInfo и Surfer [6].

Таблица 2

Сравнение значений фоновой точки и ПДК(рх)

\begin{tabular}{|l|c|c|}
\hline \multicolumn{3}{|c|}{ Точка 9. Ратмино (Фон) } \\
\hline Компонент & $\begin{array}{c}\text { Значение } \\
(\text { мг/дм })^{3}\end{array}$ & $\begin{array}{c}\text { ПДК(рх) } \\
(\text { мГ/дм })^{3}\end{array}$ \\
\hline $\begin{array}{l}\text { Взвешенные } \\
\text { вещества }\end{array}$ & 0,3 & 1,5 \\
\hline Ион аммония & 0,32 & 0,50 \\
\hline Кадмий & 0,0003 & 0,0010 \\
\hline Кальций & 0,8 & 180 \\
\hline Магний & 4,3 & 40 \\
\hline Медь & $\mathbf{0 , 0 0 2}$ & 0,001 \\
\hline Никель & 0,0004 & 0,1000 \\
\hline Нитрит-ион & 0,02 & 3 \\
\hline Общая жесткость & 0,2 & 10 \\
\hline рН & 6,6 & $6,5-8,5$ \\
\hline Свинец & 0,0019 & 0,0020 \\
\hline Фосфат-ион & 0,07 & 0,20 \\
\hline Цинк & 0,01 & 0,01 \\
\hline
\end{tabular}

По результатам исследования выявлено подщелачивание снежного покрова, а в 2020 году отмечается нейтральное значение $\mathrm{pH}$ твердых осадков. Некоторые анализируемые компоненты не были рассмотрены в исследовании 2020 года, однако по полученным данным можно сравнить аммоний-ион и нитрит-ион. Ситуация по аммоний-иону схожа, концентрации в районах города изменились незначительно, в отличие от концентраций нитрит-ионов, которые существенно снизились в 2020 году. Одна из возможных причин - разница в сроках пробоотбора, так как анализируемый снег в 2020 году был свежевыпавшим. Автор исследования [6] характеризует ситуацию в отношении загрязнения твердых атмосферных осадков как благополучную.

\section{Заключение}

По результатам анализа жидкой составляющей снега выявлено превышение ПДК(рх) по следующим компонентам: взвешенные вещества, медь, свинец, фосфаты и цинк. Несмотря на кратковременное пребывание свежего снега на территории города, в некоторых точках исследования наблюдается существенное антропогенное воздействие. Это связано с привнесением загрязнителей не только из атмосферного воздуха, но и других источников, таких как, например, автотранспорт в непосредственной близости от автодорог, а также строительные работы. Стоит отметить, что в г. Дубна небольшое количество стационарных источников воздействия, способных за короткое время оказать существенное влияние.

Вероятное поступление загрязняющих веществ в воды р. Волга и Дубна касается следующих компонентов: медь, свинец, цинк и фосфаты. Так как повышенные концентрации меди обусловлены особенностями строения исследуемой территории (г. Дубна окружен болотами), наблюдается их эмиссия в снежный покров и далее в поверхностные воды. Свинец в данном случае является антропогенным компонентом, и его превышение в снежном покрове и водах исследуемой территории, несомненно, регулируется человеческой деятельностью. В частности, источниками поступления являются химические предприятия, расположенные на территории города, а также бытовые отходы. Согласно проведенным исследованиям, повышенные концентрации цинка в снежном покрове и водах наблюдаются вблизи строительных площадок, где присутствуют растворы цемента и мелкая пыль, и вдоль автодорог. Фосфаты, обнаруженные в снежном покрове в небольшом удалении от автомоек и прилегающих дорог, содержатся и в водах Угличского водохранилища. В частности, возможными источниками поступления в поверхностные воды города являются смывы с сельскохозяйственных угодий и диффузный сток с СНТ.

Таким образом, ситуация по загрязнению окружающей среды г. Дубна является стабильно благополучной, что показывает сравнение с полученными ранее данными. Этому способствует отсутствие крупных промышленных предприятий, тем не менее необходим регулярный контроль и мониторинг для выявления залповых выбросов в окружающую среду.

\section{Список литературы}

1. Козин В.В., Кузнецова Э.А. Физико-географические факторы пространственно-временной изменчивости снежного покрова нефтегазопромыслового региона: монография. Нижневартовск: Изд-во Нижневарт. гос. ун-та, 2015. 151 с. 
Kozin V.V., Kuznetsova E.A. Physico-geographical factors of spatial and temporal variability of the snow cover of the oil and gas field region: monograph. Nizhnevartovsk: Nizhnevart Publishing House. state un-ta, 2015. 151 p. (in Russian).

2. Соловьева Н.Е., Олькова Е.А., Алябьева А.А., Краева О.В. Исследование талой воды (снега) как показатель загрязнения атмосферы урбанизированной среды // Молодой ученый. 2015. № 14 (94). С. 668-672.

Solovieva N.E., Olkova E.A., Alyabyeva A.A., Kraeva O.V. Russ. The study of melt water (snow) as an indicator of atmospheric pollution in an urbanized environment. Young scientist. 2015. No. 14 (94). P. 668-672 (in Russian).

3. Воронцова А.В., Нестеров Е.М. Геохимия снегового покрова в условиях городской среды // Известия РГПУ им. А.И. Герцена. 2012. № 147. С. 125-132.

Vorontsova A.V., Nesterov E.M. Geochemistry of snow cover in an urban environment // Izvestiya RGPU im. A.I. Herzen. 2012. № 147. P. 125-132 (in Russian).

4. Каманина И.З., Каплина С.П., Макаров О.А., Кликодуева Н.А. Комплексная оценка экологического состояния наукограда Дубна: монография. Дубна: ОИЯИ, 2019. 168 с.

Kamanina I.Z., Kaplina S.P., Makarov O.A., Klikodueva N.A Comprehensive assessment of the ecological state of the science city Dubna: monograph. Dubna: JINR, 2019. 168 p. (in Russian).

5. Информационный выпуск «О состоянии природных ресурсов и окружающей среды Московской области в 2018 году»// Министерство экологии и природопользования Московской области. [Электронный ресурс]. URL: https://mep.mosreg.ru/download/document/5089114 (дата обращения: 14.12.2021)

Information issue «On the state of natural resources and the environment of the Moscow region in 2018»// Minister- stvo ekologii i prirodopol'zovaniya Moskovskoy oblasti. [Electronic resource] URL: https://mep.mosreg.ru/download/document/5089114 (date of access: 14.12.2021). (in Russian).

6. Каплина С.П. Оценка экологического состояния компонентов окружающей среды малых и средних городов севера Московской области: автореф. дис. ... канд. биол. наук. Москва, 2013. 21 с

Kaplina S.P. Assessment of the ecological state of the environmental components of small and medium-sized cities in the north of the Moscow region: avtoref. dis. ... kand. biol. nauk. Moskva, 2013. 21 p. (date of access: 14.12.2021). (in Russian).

7. Схема водоснабжения и водоотведения городского округа Дубна Московской области на период до 2015 г. OAО «ПТО ГХ», 2015

Scheme of water supply and sanitation of the urban district of Dubna, Moscow region for the period up to 2015 - JSC "PTO GH", 2015. (in Russian).

8. ГОСТ 17.1.5.05-85: Охрана природы. Гидросфера. Общие требования к отбору проб поверхностных и морских вод, льда и атмосферных осадков. М.: Стандартинформ, 1986. 12 c.

9. Методические рекомендации по оценке степени загрязнения атмосферного воздуха населенных пунктов металлами по их содержанию в снежном покрове и почве (утв. Главным государственным санитарным врачом СССР 15 мая 1990 Г. N 5174-90)

10. Руководство по контролю загрязнения атмосферы. РД 52.04.186-89 (действует с 01.07.1991). М.: Госкомгидромет, 1991.

11. ГОСТ 31861-2012 Вода. Общие требования к отбору проб. М.: Стандартинформ. 45 с. 